\title{
ІНСТИТУТ ОСВІТНЬОГО ОМБУДСМЕНА: АДМІНІСТРАТИВНО-ПРАВОВИЙ АНАЛІЗ
}

\begin{abstract}
ЖАРОВСЬКА Ірина Мирославівна - доктор юридичних наук, професор, професор кафедри теорії та філософії права, конституційного та міжнародного права Національного університету «Львівська політехніка»

РУДАНЕЦЬКА Оксана СТефанівна - кандидат юридичних наук, доцент кафедри права економічного факультету Львівського національного аграрного університету
\end{abstract}

DOI 10.32782/NP.2021.2.7

\begin{abstract}
В статье проведен анализ административно-правового статуса институт образовательного омбудсмена. Методологической основой статьи является сравнительно-правовой метод (использована практика Нидерландов, Индонезии). Доказано, что во многих странах институт омбудсмена стал неотвемлемой частью механизма государственной власти, $и$ указывается, что в Украине правовая природа бункиионирования институту омбудсмена имеет конституционнъгй характер. Мотивировано, что в ицелом института омбудсмена присущи следующие особенности: независимость полномочий от других органов публичной власти, даже тех, которье их назначают или утверждают; особъй статус омбудсмена, уникальность такой должности в системе органов государственной власти; выступает арбитром между государством и субъектами частного права; определено законом круг полномочий и функиий; призванъ защищать права и свободь граждан или других субъектов права в общем или специальном порядке; специальнылй механизм реализачии полномочий; мониторинговая деятельность уполномоченного.
\end{abstract}

В Украине институт образовательного омбудсмена изначально введен Законом «Об образовании», принятым 5 сентября 2017 с челью обеспечения надлежащих условий для реализачии права на образование. В статье проведен анализ деятельности образования омбудсмена в Украине. В иелом следует акцееттировать, что во время пандемической угрозы и онлайн обучения его значение акту- ализировалосъ. Омбудсмен пъттается способствовать налаживанию качественного образовательного процесса.

Также он заботится вопросами вакцинаиии педагогов от COVID-19, как средства зашить не только себя самого, но и детей и нарушением права родителей доступа к образовательному уиреждению как меръ борьбы с угрозой COVID-19. Следуюшим направлением работь института образовательного омбудсмена в Украине является повычение уровня педагогических работников, мотивируя, что обеспечение качественного - образования, а также создания безопасной образовательной средъ напрямую связанъ с иифбровой грамотностью учащихся, студентов, родителей u педагогов. Неоднократно уполномоченный акцентировал внимание на качестве и наполненности смыслом типичнъгх учебнъих программ и критиковал их за чрезмерную нагрузку на учеников, таким образом въгступая за рефбормирование образования в соответствии с европейскими стандартами.

Ключевъге слова: образовательный омбудсмен, уполномоченнъии, пандемия, административные полномочия, права и свободь человека.

\section{Постановка проблеми}

Сучасна конституційна держава має три основні юридичні парадигми: верховенство права, демократія та належне управління. Гарантії прав людини є вагомим інститутом права, оскільки сприяє можливості реалізації прав та свобод 
суб'єкта права. Одним 3 новітніх видів інституційного гарантування є функціонування спеціального органу держави - омбудсмена (спеціального уповноваженого). Сьогодні інститут омбудсмена - як конституційна концепція, що характеризується самостійністю, легкодоступністю та м'якістю контролю державного управління за допомогою авторитетних осіб. Істотний внесок інституту омбудсмена у раніше згадані три парадигми вказує на суттєве значення його для захисту цих принципів, захисту прав людини, охороні законних інтересів, сприянню доброму управлінню та вдосконаленню легітимності публічноӥ влади.

\section{Стан дослідження}

Оскільки інститут освітнього омбудсмена в українській правовій політиці 3'явився менше двох років тому, у юридичній науці тільки поверхнево проаналізована ця проблематика. У першу чергу, слід звернути увагу на докторське дисертаційне дослідження I. Хомиших «Концептуальні питання теорії і практики адміністративно-правового регулювання освіти України в умовах євроінтеграційних процесів» (2019), де звернено увагу на моделі освітнього омбудсмена у світі. Також питанням займалися такі науковці, як Науменко О. П., Рижук Ю. М., Полякова І. М. та інші. Проте новітні загрози (наприклад, пандемічного, інформаційного характеру) потребують додаткового аналізу адміністративно правового статусу освітнього уповноваженого як $з$ погляду теорії, так i практики.

Метою цієї статті є адміністративноправовий аналіз інституту освітнього омбудсмена.

\section{Виклад основних положень}

Іноземний науковець М. Ремак доводить, що інститут омбудсмена - це “явище конституційного права”, що вперше було запроваджено на початку 19 століття, а потім розповсюджено у всьому світі у другій половині 20 століття. 3 моменту свого заснування інституція пройшла поступовий процес еволюції, що породжує хвилі розвитку державних омбудсменів та наслідки, що стосуються їх повноважень та завдань та в кінцевому підсумку призвело до гібридизації інституції» [1, с.63]. Незважаючи на те, що генезис такої гарантії має не таку давню історію, усе у багатьох державах світу він активно функціонує. У міжнародному праві вказано, що омбудсмен займається службою, «очолюваною незалежною публічною посадовою особою високого рангу, яка відповідальна перед законодавчою владою, отримує скарги від потерпілих на державні органи, службовців, наймачів чи діє на власний розсуд, уповноважена проводити розслідування, рекомендувати коригувальні дії та представляти доповіді» [2, c. 21].

У багатьох країнах інститут омбудсмена став невіддільною частиною механізму державної влади без порушення компетенції, наявних процедур організації роботи інших органів, інститутів, котрі забезпечують захист і поновлення порушених прав і свобод людини, без зміни функціонування їхньої діяльності [3, с.12]

В Україні правова природа функціонування інституту омбудсмена має конституційний характер. Так, ст. 101 Конституції України проголошує, що парламентський контроль за додержанням конституційних прав і свобод людини та громадянина здійснює Уповноважений Верховної Ради України з прав людини, також ст. 55 декларує, що «кожен має право звертатися за захистом своїх прав до Уповноваженого Верховної Ради України з прав людини».

Для підтвердження загальної моделі подамо досвід Нідерландів. Посада їх омбудсмена була створена Законом про національного омбудсмена 1981 року. Починаючи з 1999 року, установа була включена до складу Конституції. Відповідно до статті 78а Конституції, голландський омбудсмен повинен провести розслідування, за запитом або за запитом за власним бажанням, дії урядових та інших адміністративних органів органи влади, визначені актом парламенту або відповідно до нього. Голландський омбудсмен був створений 3 метою надання особам можливості отри- 
мати доступ до незалежного та експертного органу з розгляду скарг щодо практики управління [4, с.73]. Посада голландського омбудсмена у Конституції, як одна з найвищих посадових повноважень держави, гарантує їі незалежність та неупередженість.

Загалом інституту омбудсмена притаманні такі особливості:

- незалежність повноважень від інших органів публічної влади, навіть тих, які їх призначають чи затверджують;

- особливий статус омбудсмена, унікальність такої посади в системі органів державної влади;

- виступає арбітром між державою та суб'єктами приватного права;

- визначене законом коло повноважень та функцій;

- покликані захищати права та свободи громадян чи інших суб'єктів права в загальному чи спеціальному порядку;

- спеціальний механізм реалізації повноважень

- моніторингова діяльність уповноваженого.

Особливим трендом сучасності є існування спеціалізованих уповноважених. Слiд звернути увагу, що Україна також нині визначає правову політику відповідно до цих юридичних трендів. I Хомишин погоджується 3 нашою позицією вказуючи, що «на сьогодні для багатьох країн характерна практика введення спеціалізованих омбудсменів, які покликані захищати права та інтереси окремих категорій громадян, що потребують додаткового захисту, або які здійснюють свої функції «в межах окремої групи суспільних відносин для захисту специфічних прав громадян» [5, с. 67].

Серед таких у зарубіжних країнах можна виокремити декілька найбільш поширених: омбудсмен 3 прав дитини (найпоширеніший у країнах Европейського Союзу, Аатинській Америці); омбудсмен 3 прав літніх людей (США); омбудсмен 3 питань рівних можливостей (поширений у скандинавських країнах); військовий омбудсмен (Нідерланди, Чехія, Німеччина); омбудсмен з питань меншин; (Угорщина,
Фінляндія, Швеція); омбудсмен із захисту прав споживачів (Данія, Норвегія, Фінляндія); омбудсмен із захисту особистих даних (Угорщина, Чехія); банківські та страхові омбудсмени (США, Канада). Існує також інститут омбудсмена в системі освіти - університетські омбудсмени (в університетах Західної Европи, США). Освітній омбудсмен у Европі нині функціонує на різних рівнях: національному, регіональному й інституційному [6, с.160].

У свою чергу, О.П. Науменко вказує, що «основними елементами правового статусу освітнього омбудсмена, що визначають межі його правових можливостей, роль та місце в системі органів державної влади, є його права, обов'язки та гарантії діяльності. Обов'язки та гарантії прав ще підлягають окресленню та законодавчому закріпленню. Юридична фіксація обов'язків сприятиме належному виконанню омбудсменом своїх функцій, а правова регламентація гарантій діяльності - забезпеченню сталості цієї інституції» [7, с.195]

Отож вагомим для науки і практики є аналіз адміністративно-правового статусу спеціального уповновноваженого у сфері освіти.

Звернемося до іноземного досвіду. В Індонезії такий інститут функціонує вже досить довго і створений відповідно до Закону № 37 від 2008 про Уповноваженого 3 прав людини. Завдання спеціального освітнього омбудсмена включають наступне: отримання звітів про погане управління при наданні освітніх послуг; проведення перевірки закладів; проведення розслідувань щодо власних справ проти імовірного порушення адміністративного права у наданні освітніх послуг; координація співпраці з державними установами чи іншими державними установами та громадськими установами та приватними особи; побудова мережі; докладання зусиль для запобігання поганому управлінню у сфері освітніх послуг; та виконання інших обов'язків, передбачених законом [8].

В Україні інститут освітнього омбудсмена початково запроваджено Законом «Про освіту», прийнятим 5 вересня 2017 року з метою забезпечення належних умов 


\section{Адміністративне право}

для реалізації права на освіту. Стаття 73 вказаного закону визначає його повноваження. Зокрема, вказано мету функціонування такої інституції - «забезпечення належних умов для реалізації права особи на освіту». Він входить у систему всієї освіти та діє у структурі органів виконавчої влади, оскільки у своїй діяльності керується Конституцією та законами України, а також положенням про освітнього омбудсмена, що затверджується Кабінетом Міністрів України.

Актом підзаконної дії розширені законодавчі норми у цій сфері. Постановою КМУ від 6 червня 2018 р. № 491 «Деякі питання освітнього омбудсмена» визначено вимоги до заняття цієї посади (громадянство, проживає в Україні останні п'ять років, має вищу освіту, досвід роботи у сфері освіти або науки не менше п'яти років, вільно володіє державною мовою); завдання; права; організаційні аспекти діяльності.

До повноважень віднесено наступне:

1) сприяння реалізації державної політики, спрямованої на забезпечення права людини на здобуття якісної та доступної освіти;

2) здійснення заходів щодо додержання законодавства про освіту;

3) вжиття заходів для забезпечення належних умов для рівного доступу до здобуття освіти;

4) сприяння впровадженню інклюзивної форми навчання;

5) сприяння виконанню Україною міжнародних зобов'язань щодо додержання в Україні прав людини на освіту;

6) співпраця та взаємодія з МОН та іншими центральними органами виконавчої влади (ст. 8 Постанови).

Розуміючи, що інститут освітнього омутсмена є зовсім новим політико-правовим явищем у нашій державі (перший уповноважений призначений 14 серпня 2019 р.), усе ж можемо провести аналіз діяльності освітнього омбудсменам в Україні.

Загалом слід акцентувати, що в час пандемічної загрози та онлайн навчання його значення актуалізувалося. Омбудсмен намагається сприяти налагодженню якісно- го освітнього процесу: "нерівний доступ дітей до освіти через відсутність або нестачу комп'ютерного обладнання, поганий інтернет, психологічні особливості щодо сприйняття інформації дітьми різного віку та інші фактори вплинули на рівень знань та навичок здобувачів освіти. Але ні заклади освіти, ні держава не володіють інформацією про ці втрати і відповідно не можуть виробити певний план їх компенсації та компенсувати ці знання. Тому нам конче необхідні моніторингові дослідження рівня знань учнів під час дистанційного навчання» [9]. Служба омбудсмена проводила 08.04.2020 до 13.04.2020 опитування батьків "Навчання дітей під час карантину” що стало основою для методологічного аналізу проблемних аспектів та репрезентувала аналітичний огляду “Здоров’я та освіта: як пандемія COVID-19 вплинула на доступ до публічних послуг в Україні”. У висновку зазначені суттєві прогалини падемічної освіти.

Також він клопочеться питаннями вакцинації педагогів від COVID-19 як засобу захисту не лише себе самого, але й дітей та порушенням права батьків доступу до освітнього закладу як заходу боротьби із загрозою COVID-19. Наступним напрямком роботи інституту освітнього омбудсмена в Україні є підвищення рівня педагогічних працівників, мотивуючи, що забезпечення якісної освіти, а також створення безпечного освітнього середовища безпосередньо пов’язані з цифровою грамотністю учнів, студентів, батьків та педагогічних працівників. Акцентує також окрему увагу на навчанні учнів безпечної поведінки в Інтернеті. Таким чином уповноважений у цій царині співпрацює 3 Міністерством цифрової трансформації України.

Неодноразово уповноважений акцентував увагу на якості та наповненості змістом типових навчальних програм та критикував їх за надмірне навантаження на учнів, таким чином, виступаючи за реформування освіти відповідно до європейських стандартів. 


\section{Висновок}

Визначено актуальність інституту омбудсмена в структурі публічно-правової реальності та вказано, що йому притаманні такі особливості: незалежність повноважень від інших органів публічної влади, навіть тих, які їх призначають чи затверджують; особливий статус омбудсмена, унікальність такої посади в системі органів державної влади; виступає арбітром між державою та суб'єктами приватного права; визначене законом коло повноважень та функцій; покликані захищати права та свободи громадян чи інших суб'єктів права в загальному чи спеціальному порядку; спеціальний механізм реалізації повноважень; моніторингова діяльність уповноваженого.

Особливим трендом сучасності $є$ існування спеціалізованих уповноважених, серед яких освітній омбудсмен. Практична сфера його повноважень стосується широких питань, актуалізується в сучасних умовах та сприяє імплементації європейських освітніх стандартів.

\section{入ітература}

1. Remac M. Standards of ombudsman assessment: A new normative concept? Utrecht Law Review 2013 V. 9, Is. 3 P. 63.

2. Комарова В. В. Уполномоченный по правам человека в Российской Федерации Государство и право. 1999. № 9. C. 21-31

3. Косінов С. А. Омбудсмен як інститут контролю за владою. Теорія $і$ практика правознавства. 2015. Вип. 1(7). С. 12

4. Meulenbroek J.M.C. Klachtrecht en ombudsman: een praktische handleiding, Kluwer. 2008. P.73.

5. Хомишин I. Ю. Запровадження інституту освітнього омбудсмена в Україні Прикарпатський юридичний вісник. Вип. 4 (19). 2017. С. 66-69.

6. Рижук Ю. М., Полякова І. М. Освітній омбудсмен у системі забезпечення та захисту прав здобувачів освіти Юридичний часопис Національної академї внутрішніх справ . 2018. № 2. С. 151-162
7. Науменко О. П. Щодо правового статусу освітнього омбудсмена Альманах права. 2019. Вип. 10. С. 190-197

8. Mirta W. The Role of The Ombudsman of The Republic of Indonesia, The Representative of Bali Province. SINTESA (Jurnal Ilmu Sosial dan Ilmu Politik) 2018. Vol. 9 No. 1 C. 32-34

9. Щоб знати, як компенсувати втрати освіти під час пандемії, потрібні якісні освітні вимірювання URL: https://eo.gov. ua/shchob-znaty-iak-kompensuvaty-vtratyosvity-pid-chas-pandemii-potribni-iakisniosvitni-vymiriuvannia/

\section{INSTITUTE OF EDUCATIONAL OMBUDSMAN: ADMINISTRATIVE AND LEGAL ANALYSIS}

The article analyzes the administrative and legal status of the institute of educational ombudsman. The methodological basis of the article is the comparative law method (used the practice of the Netherlands, Indonesia). It has been proved that in many countries the institution of the ombudsman has become an integral part of the mechanism of state power and it is indicated that in Ukraine the legal nature of the functioning of the institution of the ombudsman is constitutional. It is motivated that in general the institution of the ombudsman has the following features: independence of powers from other public authorities, even those who appoint or approve them; special status of the ombudsman, the uniqueness of such a position in the system of public authorities; acts as an arbitrator between the state and private law entities; the range of powers and functions defined by law; designed to protect the rights and freedoms of citizens or other subjects of law in general or special order; special mechanism for exercising powers; monitoring activities of the commissioner.

In Ukraine, the institute of educational ombudsman was initially introduced by the Law «On Education», adopted on September 5, 2017 in order to provide appropriate conditions for the exercise of the right to education. The article analyzes the activities of educational ombudsmen in Ukraine. 


\section{Адміністративне право}

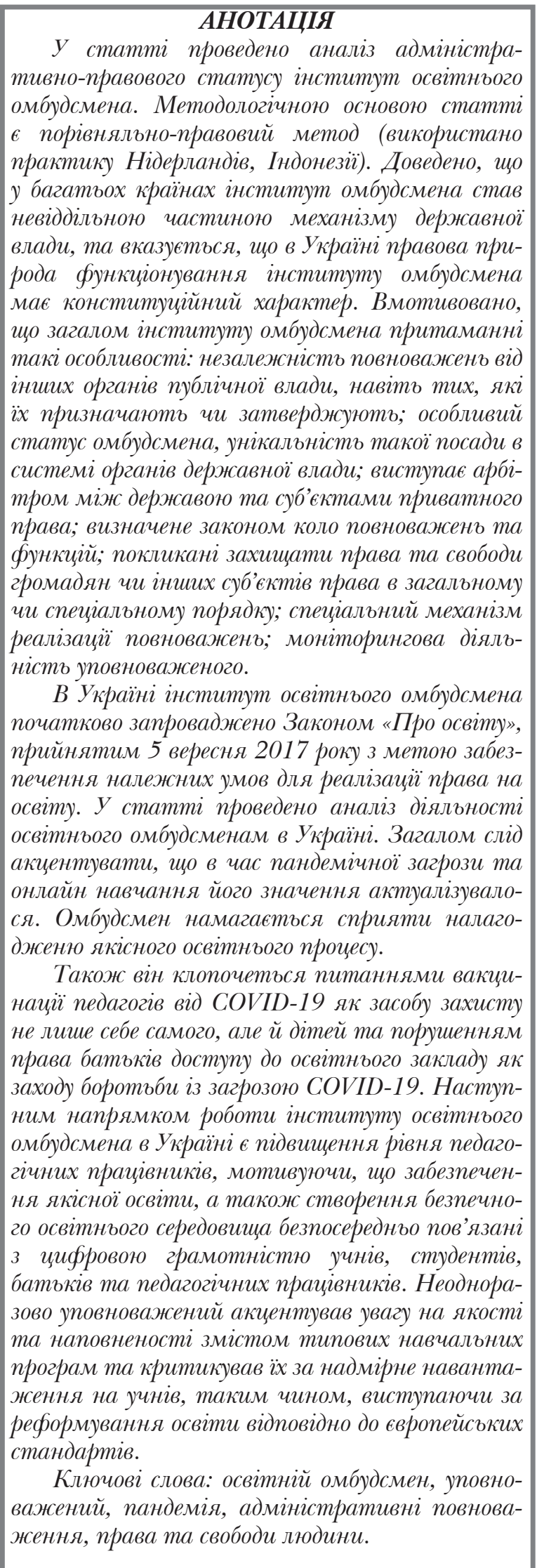

In general, it should be emphasized that during the pandemic threat and online learning, its importance became relevant. The ombudsman tries to promote a quality educational process.

$\mathrm{He}$ is also concerned about vaccinating teachers against COVID-19 as a means of protecting not only himself but also children and violating the right of parents to access an educational institution as a measure to combat the threat of COVID-19. The next direction of the Institute of Educational Ombudsman in Ukraine is to increase the level of teachers, arguing that ensuring quality education and creating a safe educational environment are directly related to digital literacy of students, parents and teachers. The Commissioner has repeatedly emphasized the quality and content of standard curricula and criticized them for overburdening students, thus advocating for education reform in line with European standards.

Key words: educational ombudsman, commissioner, pandemic, administrative powers, human rights and freedoms. 